2002

\title{
Getting at the Rapture of Seeing: Ellsworth Kelly and Visual Experience
}

Leo J. O'Donovan SJ

Georgetown University

Follow this and additional works at: https://fordham.bepress.com/phil_research

Part of the American Art and Architecture Commons, Contemporary Art Commons, Continental Philosophy Commons, and the Esthetics Commons

\section{Recommended Citation}

O'Donovan, Leo J. SJ, "Getting at the Rapture of Seeing: Ellsworth Kelly and Visual Experience" (2002). Research Resources. 39. https://fordham.bepress.com/phil_research/39

This Article is brought to you for free and open access by the Hermeneutic and Phenomenological Philosophies of Science at DigitalResearch@Fordham. It has been accepted for inclusion in Research Resources by an authorized administrator of DigitalResearch@Fordham.

For more information, please contact considine@fordham.edu. 


\title{
LEO J. O’DONOVAN, S.J.
}

\section{GETTING AT THE RAPTURE OF SEEING:}

\author{
Ellsworth Kelly and Visual Experience
}

\begin{abstract}
I propose that any depiction ... invites the eye to exercise a certain practical "interpretive" capability. The eye "interprets" the task set to it by the painting. The task is a lifeworld task, not a theoretical one; it is meaningful to the viewer in practical, descriptive, and human narrative terms.
\end{abstract}

- Patrick Heelan, S.J., Van Gogh's 'Modern' Use of Perspective

It may be exaggerated to call Ellsworth Kelly "the most profoundly classical of all American artists," as one London critic put it, but I am persuaded that his singular vision and achievement deserves even higher ranking than it has until recently received in the annals of 20 th century American art. ${ }^{1}$ A series of recent exhibitions, and in particular, the great international retrospective of 1996-1997 have added new luster to his reputation (whereas the Museum of Modern Art's equally ambitious 1996 retrospective of Jasper Johns had just the opposite effect). ${ }^{2}$ After more than 50 years of artistry, Kelly has proven himself remarkably consistent, independent, and, yes, even morally inspiring.

If abstract art has been the distinctive contribution of the 20th century, Kelly's approach to it is unique. With an oeuvre that has always combined austerity of means and sensuous delight, he is famous for distilling fragments of visual perception. But he has also reached back to Romanesque churches and Byzantine frescoes in search of essential forms. And he responded intuitively to the use of panels by expressive artists as seemingly different as Grünewald and Max Beckmann. The longer one looks at his work, the more mysteriously it reveals itself as non-referential and yet rooted, as objects existing in their own right yet ineluctably evoking endless associations.

Born in 1923 in Newburgh, New York, Kelly lived with his family in Oradell, New Jersey, and following graduation from high school moved to Brooklyn, where he briefly studied applied arts at Pratt Institute. After serving with the United States Army during World W ar II and spending time in England, France, and Germany, he enrolled for two years at the School of the Museum of Fine Arts in Boston. In 1948, the G.I. Bill allowed him to return to France and to settle in Paris, where he remained for the next six years.

An elegant draftsman, as his famous drawings of plants and flowers attest, Kelly also had a flair for expressionism, particularly evident in an early Picassoesque self- portrait

B. E. Babich (ed..), Philosophy of Science, Van Gogh's Eyes, and God: Hermeneutic Essays in Honor of Patrick A. Heelan, S.J., 295-300.

(C) 2001 Kluwer Academic Publishers. Printed in the Netherlands. 
from 1949. But in Paris, stimulated by conversations with Jean Arp and his wife Sophie, by modernists as different as Brancusi and Mondrian, and by the late cut-outs of Matisse, he found his own artistic identity - and a life-long artistic practice. His vocabulary became one of strongly defined forms or panels, juxtaposed one next to another, in unmodulated color (which he speaks of "achieving"). Within his work the distinction between figure and ground generally disappears, while the object itself is presented without any frame, directly on a wall that becomes, if one will, itself a ground. Often the artist made collages of colored paper, using chance as a composi-tional principle, and then refined the results intuitively with pencil drawings.

The monumental retrospective in 1996-1997 offered a survey of Kelly's 50-year career and a memorable opportunity to chart his development and to appreciate his wide artistic range. Among his unforgettable early works is "Meschers" (1951), a blue-green evocation of seaside experience which can be analyzed into five tall vertical panels, similar to the nine implicit panels in "La Combe I" (1950), itself inspired by a photograph Kelly took of shadows on a staircase. The small rectangular panel of "Seine" (1951) even more vitally conveys the dance of light on water, the title alone giving us the small clue we need to connect our visual pleasure with the artist's original inspiration. Before this painting, one sees how Kelly would work forever after. Abstracting an element of visual experience, he gives it pure form and separate, independent presence. One may be tempted to read the black or the white, alternately, as figure and ground. But in fact the distinction simply no longer holds and in this respect "Seine" is a homage to, and indeed rivals, Mondrian's "Composition in Line" of 1916-1917.

The perfect square of "Spectrum Colors Arranged by Chance" (1951 - 1953) is a larger statement of Kelly's style, and "Colors for a Large Wall" (1951), now in the collection of the Museum of Modern Art, more ambitious still. Coming less than a decade after "Broadway Boogie-Woogie," these paintings have great affinity with Mondrian but also an entirely different sensibility, feeling somehow closer to us, visually even more demanding but also less sovereign. They have the purity of color and dynamism of Mondrian, but they are somehow more expansive and less selfcontained.

The blur of a spring landscape or the heat of the desert may have suggested "Train Landscape" (1952-1953) and "Gaza" (1952-1956), but each of these vibrant works commands one's attention on its own terms as a magical interaction of colored form or, one might equally say, formed color. Still, recalling the fragment of visual experience behind each work can redirect one to it with a new alertness to its visual subtlety.

On seeing a reproduction of a geometric painting by Ad Reinhardt, Kelly decided New York might be a more welcoming environment and returned there in 1954. Two years later he had his first solo exhibition at the Betty Parsons Gallery, and also moved that year to a loft in a Lower East Side neighborhood called Coenties Slip, where a number of other younger artists, including Jack Youngerman, Agnes Martin, Robert Indiana, Jasper Johns and Robert Rauschenberg, had also settled.

If Kelly had discovered himself in Paris, he flourished in these early New York years. To the lyric of his geometric vision he now added experiments in biomorphic form, with reverberating results such as "Black Ripe" (1955) and "Rebound" (1959). In the latter, the viewer is drawn into ongoing visual interpretation: two ovoid forms are 
bounding against each other - or else, two pointed black forms are reaching out from the top and the bottom of the canvas to meet. The painting is remarkable for its optical effect and yet also retains a remarkably sensuous surface, pairing abstract simplicity with visual pleasure. It also returns to figure-ground tensions, as does "Broadway" (1958), a wayward, red almost-square on a white ground that teases out meaningful form depending on the angle from which one views it.

"Jersey" (1958), in brisk green and white, would make a fine new logo for the Garden State (and its shabby turnpike). But my own favorite from these early years is "Block Island II" (1960) from the Nasher collection. Here a lime green form, abstracted from the shape of the island, has been surrounded by matte black and lifted over an uninflected sea of blue, so that sea and island and the sails that first made it accessible are all magically evoked, even while the primary pleasure of abstract color and form predominates. Visual experiences of landscape and cartography have been transformed, and resonate, in an object on its own that is all the richer for the occasion of its creation.

Recalling one of his earliest works in Paris, an abstract relief of a window that fascinated him there in the Museum of Modern Art, Kelly began to produce paintings in New York that work as reliefs, as in "Orange Red Relief” (1959). He also made his first free-standing sculptures, the wittiest early example of which is "Pony" (1959). For the latter, at Agnes Martin's suggestion, he copied a crinkled tin can top into the suggestion of a child's rocking horse, painted bright yellow above and bright red beneath. All in all, nevertheless, rectilinear form remained his most frequent syntax, but varied now beyond the square and rectangle.

Moving in 1963 to the Hôtel des Artistes on the Upper West Side, Kelly moved away from the use of organic forms towards a stricter geometry, investigating subtle color relationships and emphasizing the distinction yet interrelationship of the panels that comprised his paintings. "Green Red Yellow Blue" (1965) is a remarkable example, with its four vertical rectangles in those colors hung at 9 -inch intervals. No reproduction can remotely convey the exhilarating effect of this work as one views it first from a distance, then close up, then walking past it in either direction. (The flat white wall on which it was mounted at the Tate worked especially well.) In "Yellow Piece" a year later, the shaped canvas "composes" the color, so that formed color (or colored form) asserts an identity of its own. So too in "Blue Red" (1966), in which an upright blue panel is right-angled to a red panel lying on the floor, blurring the distinction between painting and sculpture.

Kelly had been at pains to resist the popularity of Abstract Expressionism. "I didn't want an art that was so subjective," he has said. "I wanted to get away from the cult of the personality." "His own intuitive and highly creative calculation is evident in "Green White" (1968), an inverted triangle composed of a green trapezoid above a smaller white triangle. (The effect was originally suggested to him by the glimpse of a woman's scarf in Central Park.) "Yellow Black" of the same year is again a triangle, but this time tilted sideways and composed of a yellow trapezoid abutting a sharp black triangle. Daring in scale and yet strangely weightless, it seems about to lift off from the wall and into space.

In these years, Kelly was often linked and in fact confused with representatives of Hard Edge and Color Field painting, Op as well as Minimalism. That his journey had predated most of them and had another destination became even more clear when he moved in 1970 to Spencertown in upstate New York. There he rented an old theater in 
the nearby town of Chatham, which enabled him to expand his scale both vertically and horizontally. "Green Angle" (1970), for example, from the Broad collection in Los Angeles is more than 19 feet wide. In the early seventies, he also began a series of 14 paintings in the form of an inverted L formed by two panels, in each case varying the size, proportion and colors of the panels. "Chatham IX: Black Green" (1971) stands out in this series, perfectly balanced, teasingly proportioned, dramatic in its opulent color contrast.

And then there is "Blue Curve III" (1972), a marvelous rotated parallelogram in the form of a broadened diamond, in which a blue curve seems to grow as one looks at it, disengaging from a smaller white triangular shape above it and yet lending the white a magical shimmer. Kelly has wrought variations on this poetry ever since, re-imagining it in cool polished aluminum or as a blazing fan-shaped red curve of oil on canvas. The effect of these calm majestic presences is sculptural, and indeed, since his move to Spencertown, the artist has become increasingly interested in the use of materials such as wood, bronze, and weathering steel. From each he has crafted slender totemic pieces which at once recall Brancusi and take a stand of their own. Still more compelling and mysterious are several folded bronze wall pieces from the late $1980 \mathrm{~s}$, the most beautiful of which, "Untitled (Mandorla)" (1988), evokes fruit and welcome and womb - and ultimately the Romanesque tympanum in which the risen Christ reigns supreme (as in a chaste early oil of 1949).

Since 1979 , Kelly has worked in a studio that he built near his home. Increasingly he has sought effects in movement and space with more or less irregularly-shaped panels. In the gleaming white "Diagonal with Curve I" (1978) he plays with issues of similarity and contrast, balance and imbalance, as well as with the relation between the floating form and its fixed wall background. "Diagonal with Curve XIV" (1982), on the other hand, in weathering steel, with its lower left corner resting on the ground, works as both painting and sculpture. It rises and falls, soars and is grounded, lifts and leans all at the same time. And since no version of the 1997 retrospective was hung without the artist's participation, we know that it was he who exactly intended the 1986 dance of the three large panels in orange, dark gray and green. Hung with other intensely hued panels of the period, they turned the gallery space into a monumental collage with which Matisse would surely have been delighted.

Late in the ' 80 s Kelly returned to the joined, multi-panel works of earlier years. But now the colors are even more intense and the kinetic tensions more thrilling, as in "Yellow Black" (1988) and "Purple Panel with Blue Curve" (1989). Perhaps the supreme example, and surely one of the artist's masterpieces, is "Orange Red Relief (For Delphine Seyrig)" (1990) from the Museo Nacional de Arte Reina Sofía in Madrid. The earlier "Orange Red Relief" had used almost the identical color scheme and the two-panel relief format. But the later work is more luminous by far, with a glorious precarious balance. It creates a remarkable effect of falling and floating at one and the same time, its closely related colors simultaneously attracting and repulsing each other, while the overlap of canvasses evokes both resolution and dissolution. With the utmost economy of means, the artist delights our vision - and teaches it to see color and form and movement as if for the first time. Seldom has such purity seemed so sensuous.

That the range Kelly has set for himself can be limited is apparent in some works from the last decade such as "Y ellow Relief with Blue" (1991), which appears formulaic and forced. ${ }^{4}$ But these instances are rare. And the five great panel variations on the 
theme of the curve in brilliant green, black, red, blue and yellow, which held court in the High Gallery of the Guggenheim off its first ramp and climaxed the show at the Tate, attest to the extraordinary range of Kelly's art. Observing the panels, Simon Schama noted aptly in his now-famous review in The New Yorker, "Together, they appear about ready to lose their moorings from the Guggenheim walls and drift off out of the museum and over Central Park - great weightless monuments turning, rotating, and shifting like the dimly seen planetary bodies whose celestial music they seem, mysteriously, to echo." 5

At the time, much was made of the stark simplicity and more chronological hanging of the artist's work at the Tate than at the Guggenheim, where Frank Lloyd Wright's architecture regularly upstages the art exhibited in it. But for this show the Guggenheim did, blessedly, straighten the sloping walls of the tight bays on its ramps and also allowed the artist's work to be seen, and compared, at distances never previously experienced. It likewise offered the full range of the Paris years and the indispensable exhibition within an exhibition of the works on paper (including the deeply affecting pencil sketch of his deceased father in 1982).

All in all, the exhibition in its four different venues provided the opportunity to see the artist interpreted by multiple presentations and, in my view, established his place as a major figure in the history of $20^{\text {th }}$ century abstraction. The founder not of any school or movement, he was shown to be inimitable but also irreplaceable.

Kelly's work abstracts from visual experience only to return us to it. His work has always sought an objectivity which can capture our attention on its own terms, but the circumstances of his life have influenced each of his innovations, from his choice of form and color to his experiments in scale to his austere and imposing series of sculptures. The $20^{\text {th }}$ century artists he most admires, Brancusi and Mondrian, Matisse and Picasso, also tell us much about his artistic ideals. For if the former became distinctively and rigorously abstractionist, the latter never crossed that line. He also admits now that earlier in his life, in order to distinguish himself from other emerging movements, he probably emphasized the role of nature in his work too much. But throughout, the works which he insists are objects in their own right continue to echo forms we have all glimpsed less searchingly: sweeping fans and swelling hillsides, signs and semaphores and sails, totems and towers. In a way that recalls Georges Braque, he is as classical and indebted to tradition as he is contemporary and innovative, joining the illusionism of Renaissance perspective with the fragmented fields of modern experience.

"I think what we all want from art is a sense of fixity, "Kelly has said, "a sense of opposing the chaos of daily living." ${ }^{6}$ But for that, one must risk contemplation, finding the time and space to share his clear vision. And if one does? Kelly's pilgrimage amounts to a promise. "In a sense, what I've tried to capture is the reality of flux, to keep art an open, incomplete situation, to get at the rapture of seeing."

And so he does.

Georgetown University 
LEO J. O'DONOVAN, S.J.

1 Richard Dorment. "Like a Breath of Pure Oxygen.” The Daily Telegraph. June 25, 1997, 23.

2 Kelly was recognized, for example, with a monumental retrospective at the Guggenheim Museum (October 18, 1996 - January 15, 1997) that traveled, in various (and necessarily reduced) forms, first to the Museum of Contemporary Art in Los Angeles (February 16 - May 18, 1997) and then to the Tate Gallery in London (June 12 - September 7, 1997), finally showing at the Haus der Kunst in Munich (November January 1998). A handsome catalogue (Guggenheim Museum, 1996) was edited by the show's organizer, Diane Waldman. In the course of the same year of the retrospective, Kelly was awarded the Boston Museum School's first Medal for Outstanding Achievement in the Arts, an honorary doctorate of fine arts from Bard College, and sculpture commissions for Rafael Viñoly's Tokyo International Forum and the Peter B. Lewis Theater at the Guggenheim. He was also elected a Fellow of the American Academy of Arts and Sciences and, on the day I happened to see the Tate installation of the retrospective, was made an Honorary Doctor of London's Royal College of Art.

3 Holland Cotter, "A Giant of the New Surveys His Rich Past," New York Times, Oct. 13, 1996, H43.

4 Works like these may account for the criticism of Roberta Smith (who knows contemporary art as well as any observer on the scene) that Kelly sets overly narrow perimeters for his work and mistakenly distances himself from the physical possibilities of his materials.

5 "Dangerous Curves. Purity and Sensuousness: Understanding the Real Ellsworth Kelly." The New Yorker. v.72 Nov. 4, 1996, 112-116.

6 Cotter, "A Giant of the New Surveys His Rich Past," New York Times, Oct. 13, 1996, H43. 